\title{
Dom Helder Câmara e Louis-Joseph Lebret: Desenvolvimentismo e Práxis Progressista Católica nas Décadas de 1950 e 1960
}

\author{
José Henrique Artigas de Godoy \\ Professor associado do Departamento de Ciências Sociais (DCS) e do Programa de Pós-Graduação em \\ Ciência Política e Relações internacionais (PPGCPRI) do Centro de Ciências Humanas, Letras e Artes da \\ Universidade Federal da Paraíba (CCHLA-UFPB). João Pessoa, PB, Brasil. \\ E-mail: jhartigasgodoy@gmail.com, http:/ / orcid.org/0000-0002-9580-1841
}

\section{INTRODUÇÃO}

\begin{abstract}
A partir do estudo do pensamento e da ação política do arcebispo Dom Helder Câmara e do padre dominicano Louis-Joseph Lebret, busca-se observar a formação do pensamento católico progressista no Brasil nas décadas de 1950 e 1960, destacando a família de pensadores desenvolvimentistas. Nesse período, o pensamento católico progressista teve grande repercussão política e social no Brasil e na América Latina e redundou, em sua vertente mais radical, na Teologia da Libertação. A teologia partida da realidade latino-americana foi resultante de uma práxis libertadora da Igreja nas décadas anteriores, especialmente após o segundo pós-Guerra (Löwy, 1989). O artigo versa especialmente sobre essa práxis.
\end{abstract}

Mesmo em face do reconhecimento da expressiva relevância política e social do clero e do laicato católico no período, como destacado em estudos de Michael Löwy, Bresser Pereira, Marcelo Ridenti, Daniel Aarão Reis, Scott Mainwaring, Roberto Romano, entre outros, as ciências sociais pouco se dedicaram ao estudo do pensamento católico. A bibliografia sobre o tema geralmente utiliza como referência métodos característicos da teologia e da sociologia das religiões, não envolvendo o estudo sistemático do pensamento político, assim como a vertente católica do pensamento desenvolvimentista não é retratada pela literatura pertinente aos ciclos ideológicos do desenvolvimentismo (Bielschowsky, 2000). 
Os estudos de pensamento político partem da observação do pensar e do agir (Vianna, 2001), do logos e da práxis (Faoro, 1987; Brandão, 2007; Lynch, 2013), abarcando pesquisas sobre trajetórias pessoais, intelectuais e políticas a partir de perspectivas nacionais e regionais, marcadamente empreendidas em contextos periféricos. Essas pesquisas visam analisar integradamente textos e contextos, assim como as formas de transmissão e absorção das ideias por públicos e em tempos diversos. Os estudos de pensamento político passam pela construção de conexões de sentido e pela definição de "estilos de pensamento" (Mannheim, 1959) que permitam traçar famílias e linhagens intelectuais (Ianni, 2004; Brandão, 2007), classificando similaridades e distinções, aproximações e distanciamentos entre pensadores, ideias e formas de recepção. O método de "pensar o pensamento" permite definir "afinidades eletivas" (Brandão, 2007; Botelho, 2008; 2012; Löwy, 2011), com vistas à composição de uma análise multidisciplinar que integre várias dimensões, demandando o diálogo em áreas de fronteira.

Segundo Mannheim (1959:78):

No âmago desse método está o conceito de estilo de pensamento. A história do pensamento, desse ponto de vista, não é uma mera história das ideias, mas uma análise de diferentes estilos de pensamento enquanto crescem e se desenvolvem, fundem-se e desaparecem; e a chave para compreensão das mudanças nas ideias deve ser encontrada nas circunstâncias sociais em mudança, principalmente no destino dos grupos ou classes sociais que são os "portadores" desses estilos de pensamento.

A maturidade do campo de pesquisas sobre o pensamento político brasileiro é resultante de pouco mais de duas décadas de debate histórico, conceitual e metodológico inaugurado na década de 1970, com Wanderley Guilherme dos Santos e Bolívar Lamounier, e continuado com Raymundo Faoro, Roberto Schwarz, Maria Sylvia de Carvalho Franco, Antonio Candido, Alfredo Bosi e, mais tarde, Octavio Ianni, Francisco Weffort, Fernando Henrique Cardoso, José Murilo de Carvalho, Luis Werneck Vianna e Gildo Marçal Brandão. Ao historicizar o debate metodológico e conceitual, e ao traçar a cartografia dos estudos de pensamento político brasileiro, Christian Lynch (2013; 2016) demonstrou a solidez do campo de pesquisa e a consolidação dos marcos referenciais que hoje lhe servem de paradigma. Sob esses marcos, seguindo os métodos aplicados por Gildo Marçal Brandão 
(2007), são estudadas as "afinidades eletivas" que envolvem a práxis de Lebret e D. Helder, buscando descrever um viés próprio do pensamento desenvolvimentista em meio à formação de uma linhagem de pensamento católico progressista no Brasil e na América Latina. De forma exploratória, busca-se também indicar sugestões acerca da retomada pela Santa Sé da agenda eclesiástica, pastoral e profética emanada do Concílio Vaticano II e gestada pela linhagem católica progressista latino-americana.

A contextualização das trajetórias de Lebret e D. Helder procura observar aspectos biográficos, da militância juvenil, da formação intelectual, universitária, técnica, eclesiástica e filosófica dos religiosos, bem como suas redes de relacionamento, as quais reuniram intelectuais, clérigos e políticos. Destaca-se também a recepção de suas ideias e suas contribuições para o pensamento progressista e para a ação do clero e do laicato católico no Brasil e na América Latina.

Liderada pelo Cardeal D. Sebastião Leme, a cúpula da hierarquia eclesiástica brasileira foi hegemonizada pelas vertentes conservadoras da neocristandade até a década de 1940, momento em que o clero progressista ganhou expressão e passou a dirigir a Ação Católica Brasileira (ACB) e o Centro Dom Vital. Com a morte de D. Leme, D. Helder Câmara assumiu a direção das principais instituições da hierarquia católica e, mais tarde, constituiu a Conferência Nacional dos Bispos do Brasil (CNBB), instituição de fundamental importância na organização do pensamento e das ações da esquerda católica no país.

Ex-integralista, D. Helder converteu-se ao clero progressista e foi assumindo posições cada vez mais à esquerda. Entre as décadas de 1940 e 1960, alinhou-se às perspectivas do "desenvolvimentismo católico", em grande medida amparado nas ideias do movimento Economia e Humanismo, liderado pelo padre Lebret, que se tornou um de seus principais interlocutores.

Criado na França no início dos anos 1940, o movimento Economia e Humanismo representou uma alternativa às perspectivas liberais e comunistas. Suas lideranças intelectuais, como Lebret e Emmanuel Mounier, aproximaram-se das teses anarquistas e marxistas sem, contudo, assumirem o corolário do socialismo e da luta de classes. Propunha-se uma terceira via, um "desenvolvimentismo humanista". Com o olhar focado nos países do Terceiro Mundo, subdesenvolvidos 
e pós-coloniais, os intelectuais do Economia e Humanismo defendiam o planejamento e a intervenção estatal para a promoção da equidade social e do crescimento econômico. A perspectiva humanista, solidária e comunitarista, amparava-se nos documentos da Doutrina Social da Igreja, a começar pela encíclica Rerum Novarum, com claras influências do positivismo e do organicismo funcionalista de Durkheim. Entre outras referências do movimento Economia e Humanismo destacamse: o racionalismo matemático de Le Play; a sociologia e os estudos etnográficos urbanos de Halbwachs e Chombart de Lauwe e da Escola de Chicago (Park, Burguess, Mackenzie, Wirth); o empirismo de Bergson; o comunitarismo de Tönnies; o terceiro-mundismo de Alfred Sauvy; e a teoria do desenvolvimento da Comissão Econômica para a América Latina e o Caribe (Cepal). Com esse amplo e heterogêneo instrumental teórico, o movimento procurou refletir sobre os condicionantes do subdesenvolvimento e os meios para sua superação.

A superação do subdesenvolvimento deveria prever processos de diversificação produtiva e industrialização, mas com o foco principal na melhoria das condições de vida dos mais pobres e não exclusivamente no crescimento econômico. A perspectiva do desenvolvimentismo católico envolvia a elaboração de diagnósticos técnicos das situações sociais e econômicas, como princípio para o planejamento de políticas públicas voltadas para um "desenvolvimento humano e integral". Sugeriam-se ações articuladas, envolvendo o Estado, o empresariado e as associações de trabalhadores, visando à formulação de políticas de equidade que também pudessem promover aumentos de produtividade.

Embora propusessem uma pauta de reformas estruturais, como a agrária, Lebret e D. Helder se contrapunham às perspectivas comunistas, propunham um pacto social pluriclassista de perfil solidário e comunitarista. São evidentes as aproximações entre as perspectivas do desenvolvimentismo católico de Lebret e de D. Helder e o nacional-desenvolvimentismo de vertente getulista dos anos 1940 aos 1960. Nesse período, os clérigos se aproximaram dos governos de Vargas, de Juscelino Kubitschek (JK) e de João Goulart (Jango), conferindo apoio político, técnico e logístico às ações desenvolvimentistas, assim como defenderam as reformas de base. Não obstante, criticavam o clientelismo populista, o paternalismo assistencialista, a demagogia e o corporativismo sindical e estatal. 
Em 1966, na reunião dos bispos em Mar del Plata, D. Helder afirmava que as vertentes progressistas da hierarquia da Igreja possuíam uma "teologia do desenvolvimento", partida de uma "teologia da criação", envolvendo uma "ética do desenvolvimento". O corpo de princípios da "teologia do desenvolvimento" não se limitaria à formulação de teses e generalidades, chegaria à prática (Souza, 2015: 191).

Em 1954, com apoio de D. Helder, Lebret foi responsável pela coordenação da primeira pesquisa sobre as perspectivas para a industrialização do Nordeste e de Pernambuco. O trabalho foi pioneiro na reflexão sobre os meios de superação do subdesenvolvimento do Nordeste. Pouco depois, a CNBB organizou o I Congresso dos Bispos do Nordeste, que prenunciou as políticas regionais de desenvolvimento empreendidas por JK. Em face dos debates no Congresso, Juscelino convidou D. Helder para participar da criação do Grupo de Trabalho para o Desenvolvimento do Nordeste (GTDN) do Banco Nacional do Desenvolvimento Econômico (BNDE) e, mais tarde, da Superintendência do Desenvolvimento do Nordeste (Sudene).

Segundo Leme (2012), uma das vertentes principais do urbanismo brasileiro seria tributária das ideias e métodos de pesquisa de Lebret. O padre criou no Brasil a Sociedade Gráfica e Mecanográfica para Análise dos Complexos Sociais (Sagmacs), que reuniu arquitetos, engenheiros, urbanistas, economistas e sociólogos no intuito de realizar pesquisas, levantamentos e diagnósticos sobre as questões urbana e social, buscando amparar planos de intervenção para a promoção do bem-estar, especialmente dos mais pobres.

Lebret representou o Vaticano no Conselho da Organização das Nações Unidas para a Alimentação e a Agricultura (FAO), no Conselho Econômico e na Conferência da Organização das Nações Unidas (ONU). Assim como D. Helder, o clérigo também participou do Concílio Vaticano II e auxiliou na redação da encíclica Populorum Progressio, que marcou o ápice do avanço do clero progressista na Santa Sé.

A primeira visita de Lebret ao Brasil ocorreu em 1947, quando ministrou um curso na Escola Livre de Sociologia e Política (Elsp). À época, a escola era dirigida por Donald Pierson, da linhagem intelectual da Escola de Chicago. Os estudos de comunidades da Elsp se aproximavam dos métodos de pesquisa desenvolvidos por Lebret e pelo Economia e Humanismo. Entre os alunos do curso constava Lucas 
Garcez, da Escola Politécnica da Universidade de São Paulo (USP), que, pouco depois, elegeu-se governador de São Paulo. Garcez foi auxiliado por Lebret na definição de seu plano de governo, que previa ações envolvendo também estados vizinhos, inaugurando as políticas de planejamento regional. Lebret também teve decisiva participação no Plano de Ação do Governo do Estado (Page) no governo paulista de Carvalho Pinto. O Page foi coordenado por Plínio de Arruda Sampaio e teve Lebret como seu mais importante consultor. A equipe do Page reuniu militantes da esquerda católica que se tornaram discípulos de Lebret. Vários urbanistas da USP, engenheiros e arquitetos, contribuíram para as atividades da Sagmacs e também participaram do Page, estimulando a circulação das obras e ideias de Lebret na universidade. As relações entre Lebret, Garcez, Carvalho Pinto e Plínio de Arruda Sampaio aproximaram o clérigo da direção do Partido Democrata Cristão (PDC) e de outros grupos políticos em São Paulo e no país. Por sua vez, as afinidades entre Lebret e Alceu Amoroso Lima favoreceram o contato com lideranças da União Democrática Nacional (UDN).

Lebret também manteve relações com os partidos de matriz getulista, como o Partido Social Democrático (PSD), de JK, e o Partido Trabalhista Brasileiro (PTB), de Vargas e Jango. As relações entre Lebret e líderes do PTB começaram a se estabelecer desde sua primeira estadia no Brasil, quando conheceu Josué de Castro, com quem manteve uma grande proximidade intelectual, técnica e política. Lebret e Josué trabalharam juntos em várias pesquisas sobre os níveis de desenvolvimento no Brasil e no mundo. As pesquisas por eles desenvolvidas sobre os padrões alimentares e nutricionais dos trabalhadores sugeriam que a fome reduzia a capacidade produtiva do trabalhador que, por sua vez, condicionava mais fome e miséria. Lebret e Josué compuseram o Conselho da FAO da ONU, dando notoriedade internacional à luta contra a fome.

A influência do pensamento católico francês também foi intensa na formação do Movimento pela Educação de Base (MEB) nos anos 1960. Apoiado por D. Helder e pela CNBB, o MEB envolveu clérigos e leigos em ações pastorais e voluntárias de combate ao analfabetismo, o que os aproximou de Paulo Freire, que passou a orientar as ações em favor da educação popular, especialmente nas áreas rurais. 
No transcurso do processo de radicalização política dos anos 1960, enquanto os militantes da Ação Católica Brasileira (ACB), sobretudo no movimento estudantil e operário, aproximaram-se da Ação Popular (AP) e das posições revolucionárias, a CNBB criou o Conselho Indígena Missionário (Cimi) e passou a amparar a disseminação das Comunidades Eclesiais de Base (CEBs) e, mais tarde, das Comissões de Justiça e Paz e das Comissões Pastorais da Terra, intensificando as ações católicas no apoio à organização política dos trabalhadores, na luta contra a ditadura e na defesa dos direitos humanos.

Os debates iniciados com a criação das CEBs abriram caminho para a crítica aos paradigmas do Economia e Humanismo, redundando na formação da Teologia da Libertação que, diferente do desenvolvimentismo humanista de Lebret, alinhou-se ao socialismo e assumiu a tese marxista da luta de classes, sob inspiração pastoral de D. Helder.

O pensamento e a ação da esquerda católica no Brasil, particularmente sob a perspectiva do desenvolvimentismo de D. Helder, Lebret e do Economia e Humanismo, contribuíram para a formação intelectual e política de gerações de importantes lideranças brasileiras, entre elas alguns dos fundadores do Partido dos Trabalhadores (PT), como Plínio de Arruda Sampaio e Francisco Whitaker, e do Partido da Social Democarcia Brasileira (PSDB), como Franco Montoro, José Serra e Sérgio Motta.

\section{LEBRET: PESQUISA SOCIAL E DESENVOLVIMENTO}

Filho de pescadores católicos, Louis-Joseph Lebret nasceu, em 1897, em um vilarejo no litoral norte da França, Minihie-sur-Rance, vizinho ao porto de Saint Malo. Educado em colégio jesuíta, alistou-se na Marinha francesa e serviu na Primeira Guerra Mundial, como piloto e tenente. Mais tarde, cursou engenharia na Escola Naval de Brest, especializou-se em matemática e, posteriormente, em economia. Em 1922, Lebret foi nomeado instrutor da Academia Naval. No ano seguinte, abandonou a carreira militar e entrou para a Ordem dos Pregadores, ingressando no Noviciado de Angers, em Lyon, onde ordenou-se frei dominicano, em 1928 (Cestaro, 2010).

A aproximação de Lebret com a ordem dos dominicanos foi influenciada pelo pensamento do Padre Antonin-Gilbert Sertillanges, da verten- 
te neotomista. $\mathrm{O}$ movimento tomista de renovação católica mantinha fortes vínculos intelectuais com o realismo racionalista, com as observações sociais partidas de critérios empíricos, técnicos e matemáticos, orientados pela exatidão, objetividade e didatismo (Bosi, 2012).

O pensamento de Lebret também refletia o empirismo transcendental e o intuicionismo de Bergson, e os métodos de pesquisa quantitativa de Le Play, daí o uso sistemático da estatística, dos levantamentos empíricos e dos trabalhos de campo na formulação de seus diagnósticos (Lamparelli, 1994).

Interdisciplinares, as pesquisas de Lebret destacavam os problemas sociais concretos, procurando prescrever ações que conduzissem as nações e os indivíduos a um desenvolvimento humanista, integral e de caráter universal e civilizatório. O clérigo procurava demonstrar a conexão entre as diferentes esferas da vida e da natureza. Os aspectos econômicos, sociais, políticos, culturais, geográficos e ambientais se apresentariam interconectados na dinâmica social e entre nações, por isso o desenvolvimento humanista deveria ter caráter integral, concernindo todos os aspectos da vida em sociedade, e universal, envolvendo todos os povos em uma civilização solidária.

Lebret destacava a necessidade de a Igreja auxiliar na organização política dos trabalhadores, de forma que adquirissem autonomia para reivindicarem seus próprios interesses. O clérigo criticava o assistencialismo paternalista da Igreja, entendido como paliativo perpetuador dos fundamentos das desigualdades e da miséria. Era preciso combater as origens da miséria e não apenas seus efeitos imediatos. A cooperação, na contramão do assistencialismo, rompia com o paternalismo e estimulava uma cidadania ativa dos trabalhadores (Angelo, 2010).

Apesar de ter incorporado vários argumentos e conceitos de Marx, Lebret sempre se afirmou crítico da leitura política comunista da luta de classes, seguindo orientações da Doutrina Social da Igreja. Não obstante o combate ao comunismo, após a década de 1940 há sinais, nos documentos eclesiásticos, de uma moderação no que tange às críticas à vertente do socialismo democrático, procurando dissociá-lo do comunismo. Nesse contexto, fortaleceram-se grupos católicos que se aproximaram das teses socialistas e marxistas, na hierarquia eclesiástica e junto ao laicato (Soares, 2014). 
O pensamento do sociólogo Henri Desroche foi exemplar da aproximação entre o catolicismo e o marxismo. Como Lebret, Desroche foi ordenado dominicano no Noviciado de Angers. A partir de 1942, contribuiu para a consolidação do movimento Economia e Humanismo, introduzindo o debate sobre o cooperativismo comunitarista e sugerindo um diálogo da Igreja com o marxismo. Desroche teria sido um dos intelectuais mais próximos de Lebret e Mounier no Economia e Humanismo (Lamparelli e Leme, 2001:677). ${ }^{1}$

Lebret e Mounier fizeram estudos sistemáticos de clássicos do pensamento marxista e anarquista e se valeram de um conjunto amplo de conceitos e métodos dessas vertentes. Mounier passou a citar constantemente conceitos de Bakunin em seus escritos, enquanto o pensamento de Lebret se ancorou no comunitarismo de base de Kropotkin, e também na crítica ao capitalismo liberal, à superexploração do trabalho e à alienação de Marx, no método etnográfico urbano de Engels, e ainda no anti-imperialismo de Lenin.

O pensamento de Lebret tinha como referência os estudos comunitaristas e anti-individualistas de Ferdinand Tönnies e o "personalismo comunitário" de Mounier. O comunitarismo foi central para a formação do pensamento católico progressista no Brasil, que redundou na formação das CEBs.

Segundo Lebret, a busca pela superação do subdesenvolvimento dos países periféricos passava pelo combate ao imperialismo. À crítica ao imperialismo agregava-se a defesa de uma contribuição dos países ricos para o desenvolvimento dos países periféricos e para a formação de um fundo global para o combate à fome.

A questão da fome foi uma temática muito presente nas obras e ações de Lebret. O clérigo defendia a dignidade humana com base na universalização do acesso às "necessidades fundamentais", como a garantia de uma alimentação equilibrada com o suprimento de calorias, glicídios, proteínas e lipídios, o acesso a uma vestimenta adequada, ao trabalho, ao lazer, a habitações sadias, a um mobiliário básico, à água, luz e calor. Um desenvolvimento integral também deveria prever a garantia universal de serviços médicos e farmacêuticos, educação e acesso ao conhecimento e à cultura. Como as "necessidades fundamentais" representariam o mínimo à dignidade humana, envolveriam não apenas questões individuais, mas também sociais, 
como a manutenção de relacionamentos e a reserva de tempo para a reflexão, o estudo, a meditação, a oração, e a produção artística e literária. A garantia das "necessidades fundamentais" seria pressuposto para a felicidade pessoal e coletiva (Bosi, 2012).

Seguindo caminho trilhado pelos estudos de Ragnar Nurske e Gunnar Myrdall, Lebret realizou pesquisas sobre os padrões alimentares dos trabalhadores, concluindo que a má alimentação intervinha negativamente na capacidade produtiva do trabalhador, gerando como consequência um círculo vicioso, quanto mais pobreza, menores produtividades, o que condicionava mais pobreza. Para Lebret, fome e desenvolvimento seriam incompatíveis. As pesquisas de Josué de Castro apresentavam conclusões semelhantes (Lebret, 1958:1). Para Castro, "fome e subdesenvolvimento são as mesmas coisas" (Castro, 1957:27).

Reafirmando as influências recíprocas entre os dois intelectuais, Antonio Candido (1999) destacava:

O sociólogo reformador francês Padre Luis Joseph Lebret, que foi tão ligado ao Brasil e aqui trabalhou liderando o movimento "Economia e Humanismo" (e que, seja dito de passagem, sofreu a influência das ideias de Josué de Castro), tinha como lema: "É preciso criar a abundância". Ele chamava a atenção para o fato de serem as proteínas quase um privilégio, que diferençava os países pobres dos países ricos, de maneira que o mundo tinha de fazer um esforço (talvez mais difícil, porque dependia de uma revolução das mentalidades) para torná-los acessíveis a todos. Daí ter definido o conjunto das suas teorias como "economia humana", isto é, uma economia segundo a qual o lucro não apagasse o sentimento de solidariedade, mas solidariedade a fundo, papel tanto mais importante quanto, ao contrário do que se pensava, o progresso técnico tem agravado, não melhorado, a desigualdade entre os povos e a falta de alimentos. Sem uma concepção humana, o progresso material se torna fator de injustiça e miséria, entregando o mais fraco ao mais forte, na escala dos países e na escala dos grupos (Candido, 1999:2, ênfases no original).

Josué de Castro e Lebret participaram da primeira pesquisa sobre as condições de vida nas 34 maiores cidades brasileiras, patrocinada pela Comissão de Bem-Estar Social do governo Vargas (Condini, 2004:16). Pouco depois, Josué foi eleito presidente do Conselho da 
FAO da ONU, do qual já era membro desde 1943. Segundo Valladares, Josué "abrirá as portas desse organismo internacional ao seu antigo conselheiro". Em 1953, Lebret foi indicado para o Conselho da FAO como representante do Vaticano (Valladares, 2005:79).

A temática da fome e da subnutrição se articulava, nas obras de Lebret e Josué, à questão da necessidade de acabar com os latifúndios monocultores, promover a reforma agrária e o desenvolvimento amplo da agricultura familiar policultora, fundamental para superar os problemas alimentares e nutricionais dos brasileiros.

\section{RENOVAÇÃO CATÓLICA E A DOUTRINA SOCIAL DA IGREJA}

Lebret foi um defensor da reforma da Igreja católica e de suas orientações políticas e eclesiásticas. Embora tenha assumido princípios consagrados pela Encíclica Rerum Novarum, reconhecida como Carta Magna e documento fundador da Doutrina Social da Igreja, era crítico do conservadorismo papal expresso no documento, que afirmava ser a propriedade privada um direito natural e inalienável.

No sentido de justificar teologicamente a existência de desigualdades sociais, o documento afirmava que "segundo o juízo do próprio Deus, a pobreza não é um opróbio", capital e trabalho seriam antes complementares que contraditórios, a solidariedade social e cristã adviria da comunhão de interesses entre ricos e pobres em prol do bem comum (Leão XIII, 1891:13).

A Encíclica indicava que os progressos da indústria e a concentração de riqueza por um pequeno número de pessoas haviam produzido uma multidão de indigentes, assim como teriam estimulado o conflito social entre operários e patrões. Seria preciso buscar uma solução justa de compromisso entre capital e trabalho. Criticando os comunistas, a Encíclica afirmava que a incitação à luta de classes só promoveria maiores desordens sociais e instigaria "nos pobres o ódio invejoso contra os que possuem". Na esteira dessa postura, criticava veementemente os movimentos grevistas, afirmando ameaçarem a tranquilidade pública e promoverem "desordem grave e frequente", estimulando violências e tumultos. Seria preciso uma repressão do Estado contra os "agitadores" e aqueles que colocariam em risco o direito de propriedade (Leão XIII, 1891:20-25). 
Apesar da defesa da propriedade privada e dos direitos de herança (Leão XIII, 1891:7), a Rerum Novarum também tecia críticas ao liberalismo e à superexploração do trabalho, condenava a cobiça, a usura, a concentração da riqueza, o mercado financeiro e o capitalismo monopolista. O materialismo comunista seria resultante das desigualdades promovidas pelo materialismo consumista, individualista e possessivo liberal. Liberalismo e comunismo seriam faces de uma mesma moeda. Caberia aos patrões "dar a cada um o salário que convém", uma "justa medida do salário", permitindo a aproximação solidária entre capital e trabalho, ambicionando-se, assim, "estreitar a união das duas classes até as unir uma à outra por laços de verdadeira amizade" (Leão XIII, 1891:11).

Papa Leão XIII reconhecia que, quanto mais equânime fosse a distribuição da terra, menores seriam os conflitos, permitindo uma aproximação entre as classes. A garantia do direito à propriedade não poderia subsumir-se à acumulação usurária e à especulação, de forma "que a desigualdade não prejudique a concórdia" (Leão XIII, 1891:25).

A concórdia entre as classes exigiria não apenas uma repartição mais equitativa de bens, mas também uma ação compensatória do Estado que promovesse o equilíbrio e eliminasse a indigência. O Estado deveria se orientar por uma "justiça distributiva", agindo em prol da equidade (Leão XIII, 1891:19), "sem riquezas que a ponham a coberto das injustiças", a "classe indigente" teria que contar com a proteção do Estado, que deveria garantir a "providência dos trabalhadores" (Leão XIII, 1891:21).

Por um lado, as críticas à especulação, à concorrência e ao individualismo liberal e, por outro, a rejeição do estatismo autoritário e corporativista da vertente comunista amparavam a sugestão de uma terceira via que promovesse o desenvolvimento por meio de intervenções que não eliminassem as desigualdades, mas permitissem um mínimo de dignidade aos trabalhadores, assim como um maior equilíbrio social e bem-estar coletivo. A liberdade econômica não poderia sobrepor-se à liberdade humana e ao direito natural. A avareza e a acumulação teriam o dinheiro como fim, e não como meio para a promoção do ser humano (Bosi, 2012: 7). 


\section{A AÇÃO CATÓLICA E O MOVIMENTO ECONOMIA E HUMANISMO}

Editada em 1931, na gestão de Pio XI, a encíclica Quadragesimo Anno também contribuiu para a composição do arcabouço da Doutrina Social da Igreja. Além das críticas ao comunismo e ao liberalismo, também combatia o fascismo. A encíclica destacava que o socialismo tenderia para "as verdades que a tradição cristã sempre solenemente ensinou, e delas em certa medida se aproxima: portanto é inegável que as suas reivindicações concordam às vezes muitíssimo com as reclamações dos católicos que trabalham na reforma social" (Pio XI, 1931:3). No mesmo documento, entretanto, o pontífice destacava que o "socialismo religioso" e o "socialismo católico" seriam contraditórios, ninguém poderia "ser ao mesmo tempo bom católico e verdadeiro socialista" (Pio XI, 1931:12).

Em 1943, Jacques Maritain publicou Cristianismo e democracia, sugerindo um diálogo mais próximo entre a Ação Católica e o movimento socialista (Souza, 2014). Os católicos deveriam considerar os socialistas como "companheiros de combate", sugerindo uma "cooperação" que respeitasse a autonomia de cada movimento. Os católicos deveriam lutar pela justiça social para promover um "humanismo integral" (Maritain, 1945).

Maritain partia da ideia de construção social de um "humanismo cristão", que se diferenciaria do "humanismo burguês" (Soares, 2014). Enquanto este era centrado no indivíduo, aquele se ancorava em princípios sociais e coletivos.

Lebret e Mounier, seguindo Maritain, também incorporaram em seus pensamentos a tese do humanismo integral. Propunham uma vertente democrática, amparada na ideia de desenvolvimento.

Maritain foi um dos mais influentes intérpretes junto aos grupos leigos que se constituíram entre a esquerda católica no Brasil. O pensamento de Alceu Amoroso Lima, de D. Helder Câmara e de importantes líderes da Juventude Universitária Católica (JUC) e do PDC, foram diretamente tributários das ideias de Maritain. Os maritanistas no Brasil também disseminaram as leituras do Economia e Humanismo, particularmente de Lebret e Mounier, entre as associações leigas como a JUC, a Juventude Estudantil Católica (JEC) e a Juventude Operária Católica (JOC) (Souza, 2014). 
O movimento Economia e Humanismo reuniu intelectuais católicos e leigos articulados a partir da Ação Católica (AC) e da resistência francesa. Originado em Marseille, o movimento foi fundeado, a partir de 1942, no Mosteiro de La Tourette, nos subúrbios de Lyon². Lebret e outros intelectuais do movimento participaram ativamente no planejamento para a reconstrução das cidades francesas destruídas pela guerra ${ }^{3}$.

Lebret passou a ser convidado por diversos países do Terceiro Mundo para coordenar equipes de estudos para o planejamento com vistas ao desenvolvimento, visitando o Brasil, o Uruguai, o Chile, a Colômbia, a Venezuela, a Bolívia, o Peru, a Argentina, o Paraguai, o Senegal, Ruanda, Benin, Vietnã e Líbano.

Lebret criou, em 1958, o Institut de Recherche et de Formation en vue du Développement Harmonisé (Irfed), que passou a realizar cursos regulares voltados para a temática do planejamento visando o desenvolvimento, oferecidos a intelectuais, técnicos de Estado e lideranças políticas da América Latina, África, Madagascar, Médio e Extremo Oriente, especialmente dos países subdesenvolvidos e pós-coloniais (Angelo, 2010).

Em Investigación sobre lós aspectos humanos del desarrollo (Lebret, 1960), entre as demandas para a conquista de um "desenvolvimento integral e humanista" o dominicano envolvia a necessidade de formação de equipes técnicas. Pouco depois, publicou manuais de enquetes rurais e urbanas ${ }^{4}$, com o propósito de orientar as técnicas de pesquisa para a formulação de diagnósticos sociais para o planejamento de políticas públicas.

Para que haja "desenvolvimento" é preciso que se promova o aumento do número de quilômetros de rodovias e ferrovias, que aumente o número de quilômetros percorridos pelos aviões, o número de toneladas de produção, mas é necessário que a instrução aumente, - desde a instrução rudimentar que reduza o analfabetismo - é necessário que a tecnicidade aumente no plano técnico de nível médio, que o nível doméstico se eleve; também é necessário enfim que se multiplique o número de técnicos de nível superior - engenheiros agrônomos, arquitetos, urbanistas, especialistas em planejamento, valorização e utilização dos territórios. Ao mesmo tempo que em relação aos bens materiais se promove o desenvolvimento, não há razão para que fique limitado só a este aspecto: 
ele deve incluir também o desenvolvimento moral e espiritual (Lebret, 1955: IX, ênfase no original).

Havia um perigo a enfrentar no avanço das técnicas para o desenvolvimento, a simplificação tecnocrática. Seria preciso deixar claro o sentido de um desenvolvimento humano, que não se confundiria com o crescimento econômico.

Os estudos de Lebret receberam contribuições do "terceiro-mundismo católico", gestado por Albert Sauvy ${ }^{5}$. Sauvy foi um colaborador do Economia e Humanismo e responsável pelo convite para que Lebret visitasse o Chile. Em Santiago, o clérigo se encontrou com Raul Prébisch e Eduardo Frei, assim como passou a manter contato próximo com Jacques Chonchol. Líder da Democracia Cristã, Chonchol promoveu uma aproximação entre os intelectuais do Economia e Humanismo e da Cepal (Bosi, 2012:262) .

Lebret dissociava a noção de desenvolvimento dos valores característicos do homo economicus, vinculando-a antes às necessidades humanas que ao consumo de bens materiais (Cestaro, 2010). Um "desenvolvimento humano e integral" representaria a passagem de uma fase menos humana à outra mais humana, no ritmo mais rápido possível e ao mínimo custo (Lebret, 1955:X). O "desenvolvimento humanista" envolvia uma utopia que presumia uma solidariedade universal entre os homens (Lebret, 1958:4).

Na definição das políticas de desenvolvimento, Lebret destacava as escalas territorial e regional e se fiava na teoria dos "polos de crescimento" de François Perroux, também fundador do Economia e Humanismo, que previa a concentração de indústrias em áreas próximas dos grandes centros urbanos, dos locais de produção de matérias-primas e com facilidade de transporte e escoamento da produção. Os complexos industriais deveriam ser constituídos a partir de indústrias motrizes, que estimulariam a criação de unidades acessórias e subsidiárias concentradas em um mesmo território, integrando as diversas cadeias produtivas.

Lebret inaugurou uma nova concepção de planejamento urbano no Brasil ao conferir primazia ao território e à região, contrapondo-se ao pensamento urbano moderno, focado na cidade. A noção de aménagement $d u$ territoire "estaria referenciada nas ideias de bem comum, 
harmonia, integração, equilíbrio e desenvolvimento, em substituição às de embelezamento, higiene, salubridade, e monumentalidade" (Pontual, 2000:104).

\begin{abstract}
Aênfase passou a ser a explicitação de diretrizes econômicas determinantes de um futuro promissor, das quais as urbanísticas seriam decorrentes; daí o saber do planejamento sobrepujar o do urbanismo; daí a titulação de plano diretor em substituição à de plano reformador. No plano diretor, a ideia de desenvolvimento era propalada para constituir uma imagem na qual não fossem vigentes as condições desumanas de vida da população, o flagelo das secas e os males do latifúndio; não fossem quantitativamente representativas as migrações e emigrações, o analfabetismo, as endemias, as carências alimentares e a desqualificação da mão de obra, e não fossem tolhidas as organizações políticas e sociais (Pontual, 2000:105).
\end{abstract}

\title{
LEBRET NO BRASIL
}

Em 1946, o Padre Romeu Dale intermediou, com Franco Montoro, do PDC, e Cyro Berlinck, da Elsp, o convite para que Lebret visitasse o Brasil como professor visitante, para ministrar o curso Introdução Geral à Economia Humana (Angelo, 2010; Rios, 2012; Leme, 2001) 7 . Os trabalhos que Lebret passaria a realizar serviriam como um laboratório do "terceiro-mundismo católico" (Pelletier, 1996).

A viagem de Lebret ao Brasil foi patrocinada pela Federação das Indústrias do Estado de São Paulo (Fiesp), à época dirigida por Roberto Simonsen, representante das origens do pensamento desenvolvimentista no país, e fundador da Elsp. Havia claras aproximações entre o desenvolvimentismo de Lebret e o de Simonsen, como a defesa dos interesses nacionais contra o imperialismo, e de uma ampla plataforma de industrialização substitutiva de importações, com o foco principal na constituição das indústrias de base como meio de combate à pobreza e ao subdesenvolvimento. Lebret e Simonsen também compartilhavam a tese da necessidade de o Estado assumir um papel central no processo de desenvolvimento por meio do planejamento, intervindo na esfera social, econômica e cultural, com vistas a garantir saltos de modernização industrial, ampliação do mercado interno e redução das desigualdades. 
A Elsp mantinha fortes vínculos com os estudos sociológicos norte-americanos e, particularmente, com a linhagem intelectual de Chicago. Donald Pierson, que fora orientado por Robert Park em Chicago, era o diretor da escola. As investigações sobre comunidades, as etnografias urbanas e as pesquisas aplicadas empreendidas por outros docentes também aproximaram o clérigo dos intelectuais reunidos na Elsp (Chiquito, 2010).

O curso da Elsp foi chave para a formação de uma ampla rede de colaboradores e de contatos de Lebret nos meios acadêmico, político e eclesiástico do país. Entre outros alunos, encontrava-se Lucas Nogueira Garcez, da Escola Politécnica da USP (Poli). Garcez compôs a primeira diretoria da Sociedade para Análise Gráfica e Mecanográfica Aplicada aos Complexos Sociais (Sagmacs) em São Paulo, ao lado de outros engenheiros da Poli. Pouco depois, tornou-se governador do estado.

Lebret teria escrito integralmente o programa de governo de Lucas Garcez (Chiquito, 2010), que foi coordenado pelo Frei Benevenuto de Santa Cruz, discípulo de Lebret e membro da Sagmacs. O documento apresentava recomendações de execução de ações que extrapolavam as fronteiras estaduais, exigindo articulações entre estados vizinhos para a elaboração de planos regionais de desenvolvimento (Andrade e Araújo, 2016).

\section{ESQUERDA CATÓLICA E OS ESTUDOS URBANOS}

Lebret assimilou o organicismo da Rerum Novarum e foi leitor de Durkheim e Mauss. A influência das teses de Durkheim no pensamento de Lebret também envolveram os estudos etnográficos de Maurice Halbwachs. Socialista, Halbwachs estudou com Bergson, era discípulo de Durkheim, trabalhou com Mauss na Sorbonne e lecionou na Universidade de Chicago, introduzindo os estudos de Robert Park na França. O autor empreendeu um conjunto de pesquisas sobre as condições de vida dos operários das periferias de Paris, que contribuíram para os estudos urbanos de Lebret.

As pesquisas urbanas de Lebret também refletiam métodos apresentados nas investigações do sociólogo e urbanista Paul-Henry Chombart de Lauwe. No início dos anos 1940, Lauwe passou a integrar 
as fileiras da École Nationale des Cadres d'Uriage ${ }^{8}$, onde também lecionaram Emmanuel Mounier e Lebret. A partir de 1945, aderiu ao Economia e Humanismo.

Chombart de Lauwe foi o responsável pela divulgação dos métodos de pesquisa urbana da Escola de Chicago entre os intelectuais do movimento Economia e Humanismo, como Lebret, que, a partir de então, manteve aproximação com algumas teses de Chicago (Angelo, 2010; Valladares, 2005). Em seus estudos sobre métodos e técnicas de pesquisa social em ambientes urbanos e rurais refletiam-se características da Sociologia de Chicago (Angelo, 2010:41). Segundo Valladares (2012:83), as referências aos estudos norte-americanos são restritas no conjunto da obra de Lebret, ficando clara sua filiação antes à sociologia francesa de Le Play, Tourville, Demolins, Pierre Du Maroussem, Urban Guérin, Charles Peguy, Georges Balandier e Ive Lacoste, e aos estudos urbanos dos intelectuais do Economia e Humanismo, como Bardet, Desroche, Thibon, Louis Gardet, François Perroux, Teilhard de Chardin e Chombart de Lauwe. A influência norte-americana fica mais clara nos estudos diagnósticos empreendidos pela Sagmacs, como Estrutura urbana da aglomeração paulistana e Estrutura urbana da aglomeração de Belo Horizonte, diretamente referenciados pela obra $\mathrm{Pa}-$ ris et L'aglomération parisienne, publicada por Chombart de Lauwe em 1952 (Cestaro, 2009; Villaça, 1999; Pontual, 2011).

Após críticas ao governo Dutra, quando da cassação do registro do Partido Comunista Brasileiro (PCB), em 1947, o Vaticano, pressionado pelo governo brasileiro, exigiu que Lebret abandonasse o país, tendo seu retorno autorizado apenas cinco anos depois.

No retorno ao Brasil, em 1952, Lebret foi contratado pelo governo de São Paulo para realizar pesquisas e diagnósticos sobre as condições sociais e econômicas do estado e seus potenciais para o desenvolvimento, que envolveu parte da equipe da Sagmacs ${ }^{9}$. Com escritórios em São Paulo, Rio de Janeiro, Belo Horizonte e com atividades no Recife, a Sagmacs foi responsável pelos estudos para a formulação dos primeiros planos diretores de São Paulo, Rio de Janeiro, Belo Horizonte, Recife e Vitória, assim como de Barretos, Ipatinga, Ourinhos, São Vicente, Sorocaba e Ubatuba. As equipes da Sagmacs também realizaram estudos diagnósticos e formularam planos de desenvolvimento para os estados do Paraná, São Paulo, Mato Grosso, Rio Grande do Sul e Pernambuco. 
Carvalho Pinto, eleito governador de São Paulo em 1959 pelo PDC, foi influenciado pelo pensamento de Lebret, assim como envolveu a Sagmacs no planejamento das ações de sua gestão. Plínio de Arruda Sampaio, membro da vertente mais progressista do partido, foi o coordenador da equipe responsável pelo planejamento dos programas e prioridades de ação do governo, o Page, que contou com a assessoria técnica de Lebret, o que lhe permitiu ampliar sua rede de colaboração com as lideranças democratas cristãs.

Francisco Whitaker, que também participou do grupo de apoio técnico do Page, dizia que Carvalho Pinto teria sido o inaugurador das políticas de planejamento. Seu plano para o desenvolvimento era influenciado pelas ideias de Lebret, por meio do qual Plínio teria incorporado em seu planejamento os princípios do Economia e Humanismo (Buzzar, Cordido e Simoni, 2012).

As equipes da Sagmacs não eram apenas técnicas, eram, antes de tudo, militantes (Angelo, 2010:34). Engajadas e diversificadas, buscavam unir o conhecimento técnico à ação política, a formulação teórica à prática profissional em prol da transformação social (Lamparelli; Leme, 2001:676).

Apesar de ter publicado uma extensa bibliografia, que contribuiu significativamente para o debate econômico, técnico, político e eclesiástico, Lebret jamais foi um acadêmico, ao contrário, era um homem de ação. Celso Furtado, que o conheceu na época da fundação da Sudene, ao destacar a grande capacidade de articulação e ação do clérigo, dizia que Lebret era "uma usina" (Bosi, 2012).

Após as pesquisas sobre as condições de vida das populações das periferias de São Paulo e Belo Horizonte ${ }^{10}$, a Sagmacs foi contratada para realizar o primeiro estudo sobre as favelas do Rio de Janeiro. O estudo ficou sob a responsabilidade da Sagmacs e de D. Helder Câmara e redundou na publicação, em 1960, de Aspectos humanos da favela carioca ${ }^{11}$.

Os estudos sobre as favelas no Rio foram o estopim para uma longa e profícua aproximação intelectual e política entre Lebret e D. Helder Câmara (Valladares, 2005:89). 
Em 1947, durante a primeira estada do Padre Lebret no Brasil, Dom Helder já havia solicitado à Sagmacs de São Paulo uma pesquisa sobre o hábitat operário. A partir dessa experiência, Dom Helder passou a confiar na competência desse Padre-pesquisador, além de sabê-lo capaz de coordenar equipes, mesmo fora da França (...) podemos afirmar que os laços estabelecidos após essa primeira colaboração foram muito fortes. Além disso, as orientações teórico-políticas do Padre Lebret eram totalmente compatíveis com as de Dom Helder, aliado de peso durante os momentos difíceis de sua permanência no Brasil (Valladares, 2005:84).

\section{HELDER CÂMARA: PROFETA DOS POBRES}

Filho de uma tradicional família de Fortaleza, que reunia jornalistas, advogados e políticos influentes, Helder Pessoa Câmara nasceu em 1909. Aos 14 anos, ingressou no Seminário da Prainha, onde iniciou sua preparação para a vida eclesiástica. Em 1931, ordenou-se sacerdote e passou a unir o apostolado com a ação política engajada, envolvendo-se com projetos de educação popular, voltados especialmente para operários e empregadas domésticas. Ainda como seminarista, auxiliou na formação e fortalecimento de movimentos católicos como a Legião Cearense do Trabalho, os Círculos Operários, a JOC, a Sindicalização Operária Católica Feminina, a Liga dos Professores Católicos do Ceará e a Liga Eleitoral Católica (Rocha, 2009:6). Logo após sua ordenação, em 1932, a convite de Plínio Salgado, alinhou-se à Ação Integralista Brasileira (AIB), passando a ser seu principal propagandista no Ceará. Mais tarde, convertido ao clero progressista, dizia que sua militância integralista fora um "pecado de juventude". Em 1936, transferiu-se para o Rio de Janeiro e, influenciado pelo pensamento de Maritain, a ele apresentado por Alceu Amoroso Lima, abandonou definitivamente as fileiras do integralismo:

Eu saí em 1937 (...) Percebi que estava errado e me converti. Percebi que o mundo não se divide verdadeiramente em direita e esquerda e sim entre o mundo dos mais ricos e o mundo da imensa multidão de pobres. (...) Só não muda de pensamento quem não tem pensamento para mudar. Eu penso, por isso mudo (...) E quero continuar mudando sempre (Barros, 2011:132). 
Em função de sua experiência no campo educacional, D. Helder foi indicado para o Conselho Superior de Ensino do Ministério da Educação. Paralelamente, a convite do Núncio Apostólico do Brasil, Dom Carlo Chiarlo, foi indicado para o cargo de conselheiro da Nunciatura do Rio de Janeiro. Enquanto emissário do Núncio, participou ativamente dos primeiros debates sobre desenvolvimento regional, que redundariam nas primeiras políticas nacionais de planejamento regional.

Recém-titulado, o Monsenhor Helder assumiu o Secretariado Geral da $\mathrm{ACB}$, em 1947, dando início à reforma de seus estatutos e à preparação para a criação de uma Conferência de bispos brasileiros. Essa instituição assumiria a função de discutir os problemas do país e, de forma organizada, colaborar para a promoção de soluções.

A liderança nacional de D. Helder se amparava no avanço do clero progressista, especialmente no Nordeste, onde os padres vinham defendendo a luta pela reforma agrária e apoiando as organizações sociais. Um documento assinado por D. Inocêncio Engelke, em setembro de 1950, apresentado na I Semana Ruralista, deixou explícita a postura que se tornaria hegemônica na Igreja católica brasileira em defesa da reforma agrária. Mais tarde, em 1954, a CNBB assumiu institucionalmente a defesa da reforma agrária. Em 1961, a entidade procurou coordenar as ações da Ação Católica Rural, da Juventude Agrária Católica e da Liga Agrária Católica, no sentido de ampliarem-se os mecanismos de auxílio e organização dos trabalhadores do campo (Neto, 2012:66).

Logo após a reforma dos estatutos da ACB, em 1950, Câmara criou as entidades da Ação Católica Especializada, acompanhando as vertentes francesa e belga do clero progressista. Assim, formaram-se a Ação Universitária Católica (AUC), a Ação Operária Católica (AOC), a Juventude Agrária Católica (JAC), a Juventude Estudantil Católica (JEC), a Juventude Independente Católica (JIC), a Juventude Operária Católica (JOC) e a Juventude Universitária Católica (JUC).

Com influência direta do pensamento católico francês e, particularmente, do Economia e Humanismo, a ACB foi a principal instituição organizadora do laicato católico e das ações do clero progressista nos anos 1950 e 1960 no Brasil (Schallenmueller, 2010:16). 
A direção da União Nacional dos Estudantes (UNE) foi controlada pelos grupos alinhados à JUC no início dos anos 1960 e, mais tarde, pela AP, que, embora não religiosa, tinha vínculos históricos com a entidade católica (Ridenti, 1998; Silva, 2011).

Em 1952, D. Helder articulou e fundação da CNBB e assumiu sua direção. Em audiência com o subsecretário de Estado do Papa Pio XII, Monsenhor Giovani Batista Montini, futuro Papa Paulo VI, D. Helder argumentava em favor da criação da CNBB:

(...) nós temos, no Brasil, a possibilidade de criar um modelo quase ideal de relacionamento entre Igreja e Estado. O catolicismo entre nós não tem o estatuto de religião oficial, mas há grande respeito mútuo entre Igreja e o governo, e trabalhamos em leal colaboração. Uma assembleia episcopal será um instrumento que facilitará enormemente esta colaboração (Piletti e Praxedes, 1997:183).

D. Hélder era muito influente e gozava de boas relações com os principais políticos do país. Seu "desenvolvimentismo católico" se alinhava à perspectiva de pacto de compromisso nacional-desenvolvimentista e, até o golpe de 1964, a CNBB apoiou amplamente as políticas governamentais desenvolvimentistas (Barros e Oliveira, 2000: 30; Schallenmueller, 2010).

Com organização de D. Helder ocorreram, no Rio de Janeiro, em 1955, o XXXVI Congresso Eucarístico Internacional e a I Conferência Geral do Episcopado Latino-Americano, que representaram a consolidação da guinada progressista da Igreja católica no Brasil e na América Latina. A Conferência originou o Conselho Episcopal Latino-Americano (Celam), articulado por D. Helder e pelo maritanista chileno D. Manuel Larraín. O Celam colocou D. Helder em contato com uma ampla rede de clérigos e teólogos progressistas da América Latina, e abriu caminho para uma profunda transformação doutrinária da Igreja na região.

Pouco após o Congresso Eucarístico, D. Helder fundou a Cruzada de São Sebastião, com vistas ao enfrentamento do problema habitacional e das péssimas condições sanitárias e de vida nas favelas cariocas. A Cruzada foi uma das primeiras experiências de habitação popular no país (Valladares, 2005; Angelo, 2010). 
Na contramão do paternalismo assistencialista da Fundação Leão XIII, fundada por D. Leme, a Cruzada de São Sebastião procurava estimular o surgimento de lideranças locais e promover a organização das comunidades faveladas para que estas pudessem reivindicar direitos de cidadania e políticas públicas de equidade (Schallenmueller, 2010). Fruto das articulações entre a Cruzada, empresários e os governos estadual e federal, foram implementadas as primeiras experiências de urbanização de favelas, construídos os primeiros conjuntos habitacionais, e criado o primeiro banco popular do país, o Banco da Providência (Condini, 2004).

No âmbito das ações da Cruzada, D. Helder tornou-se responsável pela pesquisa Aspectos humanos da favela carioca, coordenada por Lebret e executada pela Sagmacs. Era preciso conhecer as realidades vividas pelos mais pobres para a formulação de ações de cooperação técnica, mediação e amparo. Buscava-se a construção de meios democráticos de organização social, alheios à dependência clientelista, paternalista, personalista e autoritária, que seriam expressões características do populismo e do comunismo (Valladares, 2005; Angelo, 2010).

D. Helder reconhecia que as ações da Cruzada eram paliativas. As conclusões dos estudos de Lebret realizados nas periferias das grandes cidades brasileiras e nas favelas de São Paulo e do Rio de Janeiro apontavam no mesmo sentido. A causa do crescimento das favelas se relacionava com o êxodo rural, que só poderia ser interrompido por uma reforma agrária profunda (Lebret, 1955).

Para D. Helder, assim como para Lebret, seria preciso atacar as causas das desigualdades e das injustiças sociais, principalmente a concentração da renda e da propriedade e a superexploração do trabalho. A mudança das estruturas exigiria uma reforma agrária e urbana, uma política econômica redistributiva. Essas transformações estruturais, entretanto, só poderiam advir de um processo de mudança de mentalidades, originado nas escolas, nos sindicatos, nas discussões sobre direitos e deveres, na politização da sociedade. Seria preciso conscientizar não apenas as massas, mas também as elites (Piletti e Praxedes, 1997:255).

No Manifesto por uma civilização solidária, de 1959, Lebret afirmava que não eram suficientes as medidas corretivas e paliativas em "uma economia que engendra por si o mal humano". D. Helder, por sua 
vez, dizia que as "raízes mais fundas do mal" seriam originadas dos interesses dos países ricos e da cumplicidade dos ricos dos países pobres, que permitiriam a reprodução da miséria e da injustiça, que teria consequências mais profundas nos países do Terceiro Mundo (Condini, 2004:13).

As estratégias para o desenvolvimento exigiam uma prioridade à educação popular. $\mathrm{O}$ analfabetismo era entendido pela vertente progressista como um entrave ao desenvolvimento e um impeditivo à participação dos pobres na vida política da nação. Em paralelo ao movimento pela erradicação do analfabetismo caminhava aquele em favor do voto do analfabeto. Nesse sentido, no início dos anos 1960 a CNBB, por meio do empenho de D. Helder, de D. Eugênio Sales e de D. José Távora, articulou o MEB, que procurava alfabetizar as massas, mas também, e principalmente, politizá-las (Rodrigues, 2013: 256; Ferreira, 2009; Quiroga, 2011).

\section{O CONCÍLIO VATICANO II E A POPULORUM PROGRESSIO}

A posse de João XXIII representou uma guinada à esquerda na hierarquia eclesiástica. $\mathrm{O}$ movimento de renovação foi dirigido para a retomada da pauta social da Igreja. No natal de 1961, o pontífice convocou o Concílio Vaticano II, que buscava promover um aggiornamento católico. Era preciso ouvir os "sinais dos tempos" para mudar e adaptar a Igreja à nova realidade mundial (Soares, 2014).

A definição da pauta do Concílio passou por uma grande preparação anterior, na qual o Vaticano procurou ouvir os bispos. Para tanto, lançou a circular vota et consilia, perguntando aos clérigos quais deveriam ser os temas principais a serem tratados no encontro ecumêmico.

Em seu vota, D. Helder defendia o envolvimento dos cristãos na promoção dos povos menos desenvolvidos, uma maior aproximação entre a Igreja, as artes e as ciências, um maior engajamento político e estreitamento das relações com a sociedade civil e, ainda, a ampliação das ações concretas para a promoção dos povos dominados, dos trabalhadores e dos apátridas (Soares, 2014). As vitórias das tendências progressistas no Concílio em grande medida se deveram à capacidade pessoal de articulação política de D. Helder, que foi a liderança mais destacada nos corredores e nas reuniões de gabinetes. 
Durante o Concílio não apareceu na tribuna da sala conciliar. Entretanto, sua presença infatigável nos corredores, longas palestras com o Cardeal Suenens, o bispo belga Smedt e tantos outros, encontros e almoços na Domus Mariae, onde se hospedavam os bispos brasileiros, foram decisivos para os rumos abertos do Concílio (Souza, 2009:3).

A participação ativa do episcopado brasileiro foi expressiva na articulação do Concílio. As reuniões na Domus Mariae deram origem a três grupos que se articularam por fora das atividades conciliares, o Ecumênico, formado por secretários-gerais de diversas conferências episcopais de todo o mundo, o Grupo da Pobreza, que reunia bispos na defesa de uma Igreja despojada e voltada para os pobres, e o Opus Angeli, que reunia os peritus indicados pelo Vaticano, pastores e teólogos convocados para auxiliar na condução das discussões conciliares, embora sem direito de voto. D. Helder e Lebret participaram do Concílio como peritos e intervieram decisivamente para a formulação dos documentos que seriam elaborados pelo grupo Opus Angeli, entre eles o chamado Esquema XIII, que serviu de base para a redação do documento mais progressista produzido pelo Concílio, a Constituição Pastoral Gaudium et Spes.

Esse documento, ponte fundamental com o mundo moderno, foi introduzido por pressão de cardeais e bispos centro-europeus e D. Helder, assessorado em Roma pelo Pe. Lebret, tomou parte ativa nas negociações que o impuseram (Souza, 2009:3).

A pauta elaborada pelo clero progressista da América Latina, com direta contribuição de D. Helder, Lebret e Larraín, previa discussões sobre a colegialidade do episcopado, sobre o ecumenismo, um posicionamento engajado da Igreja frente aos problemas mundiais, uma luta contra a desigualdade entre países e entre ricos e pobres.

Em maio de 1961, meses antes do início do Vaticano II, convocado no natal, João XXIII publicou a Encíclica Matter et Magistra, na qual deixava clara a recomposição da agenda social da Igreja. Retomando os demais documentos da Doutrina Social, a Matter et Magistra combatia o comunismo e o liberalismo, não obstante, dava outro entendimento acerca da questão da propriedade privada, rompendo a tradição interpretativa inaugurada na Rerum Novarum. Seguindo Maritain, João XXIII entendia que o direito de propriedade deveria ser condicionado à sua função social. A Encíclica por ele publicada retomava os prin- 
cípios da Rerum Novarum e da Quadragesimo Anno no tocante a seus fundamentos sociais, mas dedicava também uma seção às "ampliações" dos entendimentos da Encíclica de Leão XIII. Além de retomar a pauta social da Igreja, defender que as nações desenvolvidas auxiliassem as subdesenvolvidas, e a necessidade de uma ação solidária e não consumista dos indivíduos, de uma justiça distributiva, de uma maior equidade social e dignidade humana, incorporou outros temas centrais dos ideais do Economia e Humanismo, como a defesa do comunitarismo multifamiliar, do cooperativismo agrícola e industrial, do estímulo à pequena e média propriedade de agricultura familiar, além de um maior planejamento e intervenção do Estado para o estímulo ao equilíbrio social, tendo como objetivo maior a promoção do bem comum e da dignidade humana (João XXIII, 1962:3).

Dois meses antes de sua morte, após a primeira das quatro sessões do Concílio, João XXIII ainda teve a oportunidade de publicar a Encíclica Pacem in Terris, na qual defendia garantias sociais mínimas à dignidade, reproduzindo quase literalmente as palavras de Lebret (João XXIII, 1963:3). Também constava da Encíclica a defesa da educação básica, do acesso à cultura, à formação técnica e profissional e ao ensino superior, assim como aparecia com destaque a "paridade de direitos e deveres entre homem e mulher" (João XXIII, 1963:7).

O reconhecimento dos direitos aos bens indispensáveis à dignidade não seria suficiente, a Igreja deveria se esforçar para garantir a todos o acesso efetivo a esses direitos, estimulando a organização social e política dos mais pobres.

João XXIII reafirmava que o bem comum consistiria em condições da vida social que promovessem o desenvolvimento integral da personalidade humana. A equidade exigiria o auxílio prioritário aos mais fracos. Os argumentos seguiam os referenciais do Economia e Humanismo, defendiam um progresso social como condicionante do desenvolvimento, que não poderia ser pensado apenas no aspecto econômico.

As Encíclicas de João XXIII advogavam por uma aproximação da Igreja com os movimentos sociais de cristãos e também de não cristãos, abrindo a instituição a todos os homens do mundo (João XXIII, 1963:64). 
Com a morte de João XXIII, o Cardeal Montini, também amigo pessoal de Maritain, de Lebret e de D. Helder, tornou-se Papa Paulo VI, assumindo a responsabilidade de dar continuidade ao Concílio.

De acordo com o teólogo Ivanir Rampon,

a amizade entre D. Helder Camara e Paulo VI teve reflexos para além da relação que ambos mantiveram ao longo de quase 30 anos. Para ambos, o Concílio Vaticano II tornou-se uma missão (Rampon, 2014:3).

Em cartas trocadas com D. Helder, Paulo VI destacava querer sempre saber as opiniões do bispo, pois as considerava de "suma importância". As conversas entre os dois teriam sido constantes antes do início da segunda sessão do Concílio, em setembro de 1963.

De acordo com Piletti e Praxedes (1991), em meados da década de 1960, Paulo VI teria tecido comentários sobre a importância do pensamento de D. Helder não só para o Brasil, mas para o mundo todo:

Qualquer ato seu, qualquer palavra sua tem ressonância mundial. É mais importante para a imprensa europeia e norte-americana saber o que você pensa do que conhecer o pensamento de qualquer cardeal, mesmo norte-americano. (...) Graças a Deus nos conhecemos há tanto tempo (...) lembre-se de que não há, na Igreja, muitos cuja voz seja ouvida como a sua (Piletti e Praxedes, 1991:359).

Entre os temas centrais da segunda sessão do Concílio constavam o da colegialidade do Episcopado. A formulação da proposta derivou das reuniões de D. Helder com presidentes de Conferências de Bispos da África, Ásia e América Latina, ocorridas na Domus Mariae, as quais ganharam a denominação de Interconferência. O conjunto dos bispos articulados por D. Helder foi chamado de grupo dos 22 (Beozzo, 2008).

Entre a segunda e a terceira sessão do Concílio, a situação política no Brasil se radicalizou. Visando reduzir sua expressão pública, D. Jaime de Barros Câmara, o conservador arcebispo do Rio de Janeiro, articulou junto ao Núncio Apostólico para que este requeresse à Santa Sé a transferência de D. Helder, bispo auxiliar, para outra Arquidiocese. Em março de 1964, D. Helder foi indicado para a Arquidiocese de 
São Luís, com pouca expressão nacional. Não obstante, pouco depois da indicação, mas antes da publicação do ato de nomeação, com a morte do arcebispo de Olinda e Recife, abriu-se uma brecha para que D. Helder articulasse junto ao Núncio Apostólico, D. Armando Lombardi, seu amigo de longa data, para que este sugerisse a Roma sua transferência para Pernambuco, sugestão prontamente atendida pela Santa Sé (Barros e Oliveira, 2000:48).

Poucos dias depois, Castelo Branco conduziria o golpe civil-militar, dando fim à luta em defesa das reformas de base propostas por João Goulart. D. Helder e Lebret eram aliados de Jango e, logo após a deposição do presidente, passaram a sofrer censuras, perseguições e ameaças.

A ação da Sagmacs foi interrompida bruscamente com o golpe de 64. (...) a equipe técnica se vêsem nenhum trabalho, os onze contratos em andamento caem por terra, então há um completo esvaziamento do escritório, tendo como consequências visitas do pessoal do Dops, a procura do Lebret (...) há uma debandada geral (...) alguns entram na clandestinidade, outros saem do país e os que permaneceram, se dispersaram. Estavam definitivamente encerrados os destinos dos grupos e equipes da Economia Humana e Sagmacs no Brasil (Lamparelli e Leme, 2001:686).

As declarações de D. Helder em favor dos mais pobres e contra as injustiças sociais, contra a ditadura e na defesa dos direitos humanos deram ensejo à mobilização de uma ampla campanha de difamação movida contra o clérigo, que passou a ser chamado na imprensa de "arcebispo vermelho" e de "comunista".

D. Helder assumiu a Arquidiocese Metropolitana de Olinda e Recife em abril de 1964, proferindo um discurso profético em sua posse que, seguindo as posturas defendidas no concílio, voltou-se para todos os homens de boa vontade, de todos os credos e ideologias, em prol de uma Igreja mais aberta e da opção preferencial pelos pobres (Condini, 2004:26).

Imediatamente após o golpe, D. Helder se manteve neutro, o que lhe permitiu transitar pelos diversos grupos políticos, mas sua imparcialidade logo foi rompida com críticas cada vez mais contundentes contra o autoritarismo, a censura, a violência e a negação sistemática dos direitos humanos. 
Em outubro de 1964, a direção da CNBB foi substituída e passou a ser hegemonizada pelos grupos conservadores, alinhados ao novo regime.

Pouco antes do final da última sessão do Concílio Vaticano II, em novembro de 1965, na Catacumba de Santa Domitila, um conjunto de 40 padres e bispos, sob a articulação de D. Helder, firmaram o "Pacto das Catacumbas", que originou um sintético documento com 13 parágrafos. Em linhas gerais, o sentido principal do pacto referia-se à defesa de uma Igreja servidora e pobre, sugerindo que os clérigos abdicassem de toda forma de luxo e privilégios e passassem a viver com simplicidade, demonstrando solidariedade com os mais pobres. $\mathrm{O}$ "modo ordinário" de vida deveria concernir às formas de habitação, alimentação, transporte etc., mas também deveria se expressar pela renúncia à "aparência e à realidade da riqueza, especialmente no traje (fazendas ricas, cores berrantes), nas insígnias de matéria preciosa". Os religiosos deveriam ser menos administradores e mais pastores e apóstolos, aproximando-se do povo, sugerindo um caminho de secularização da Igreja.

O "Pacto" defendia a opção preferencial da Igreja pelos pobres e pelos países subdesenvolvidos, buscando a justiça, a igualdade e o desenvolvimento humano integral, "do homem todo e de todos os homens", repetindo frases constantes nas obras de Maritain e Lebret.

D. Helder considerou "revolucionária" a aprovação no concílio da Declaração sobre a liberdade religiosa e, em seguida, da Gaudium et Spes. A vitória do Esquema XIII teria representado a consagração do clero progressista dos países do Terceiro Mundo.

A Gaudium et Spes, que teve a colaboração direta de Lebret e D. Helder em sua redação, em primeiro plano se voltava para "todos os homens de boa vontade", inclusive os não crentes, para a "reta construção do mundo no qual vivem em comum". O homem é tratado no documento conciliar em sua unidade e integralidade. A Constituição Pastoral retomava a necessidade de a Igreja ouvir os sinais dos tempos, no sentido de responder às questões mais urgentes da humanidade. Era preciso reaproximar os jovens e as massas da Igreja, expressando valores condizentes com a realidade contemporânea.

A Gaudium et Spes tratava dos países em desenvolvimento e pós-coloniais, que deveriam participar de forma mais equitativa dos bens 
da civilização. Os povos oprimidos pela fome deveriam interpelar os ricos; as mulheres deveriam exigir igualdade; os operários e camponeses, salários dignos e o necessário para o desenvolvimento de suas qualidades humanas, assim como deveriam participar de forma mais ativa na vida política e econômica. $\mathrm{O}$ acesso aos bens culturais deveria se universalizar. Retomando Aristóteles, o documento afirmava a natureza social do homem e a exigência de uma humanização das relações sociais.

Seria preciso construir "homens novos", que encampassem uma nova concepção de humanidade, para almejar, então, a superação definitiva das desigualdades e a promoção da fraternidade. As mudanças exigidas passavam por ações concretas. Embora a missão da Igreja fosse religiosa, não poderia deixar de assumir a responsabilidade política, econômica e social para a promoção dos pobres e do bem comum (Vaticano II, 1965:40-42).

Em 1966, faleceram D. Manuel Larraín e Lebret, amigos e consultores de D. Helder, que tiveram imprescindível participação nas articulações do concílio. D. Helder chamava Lebret de "mestre do desenvolvimento" (Piletti e Praxedes, 1997:412).

Antes de suas mortes, Lebret e Larraín colaboraram na redação da Encíclica Populorum Progressio, publicada por Paulo VI em 1967, que representou o ápice do avanço do pensamento desenvolvimentista na Igreja. A encíclica refletia diretamente as ideias do Economia e Humanismo, citava a obra Dinâmica concreta do desenvolvimento, de Lebret - de onde retirou trechos inteiros -, assim como estudos sobre a América Latina de D. Manuel Larraín, e sobre o "humanismo integral" de Maritain.

Recuperando o princípio conciliar de uma Igreja servidora e pobre, o documento pontifício defendia a luta contra a fome, a miséria e a ignorância, e a urgência de ações solidárias em prol do desenvolvimento dos países pobres. O diagnóstico apresentado partia da afirmação de que o problema social havia se tornado um problema mundial. A fome e o subdesenvolvimento dos países do Terceiro Mundo teriam suas origens no capitalismo, no colonialismo e no imperialismo. $\mathrm{O}$ "drama mundial" teria causas estruturais fundadas no capitalismo liberal e nos interesses das classes política e economicamente dominantes. Os povos ricos se desenvolveriam rapidamente, enquanto os 
pobres o fariam em velocidade menor, amplificando os desequilíbrios, os conflitos e a violência (Paulo VI, 1967:1).

A Populorum Progressio concluía que as iniciativas individuais e locais não seriam mais suficientes para o enfrentamento dos problemas do mundo, era preciso ações conjuntas e articuladas, envolvendo aspectos econômicos, sociais, culturais e também espirituais no sentido de um "desenvolvimento integral e humano" (Paulo VI, 1967:13-14).

As preocupações com o desenvolvimento não deveriam se pautar por interesses imediatos e circunstanciais, mas por mudanças de longo prazo, que combatessem o materialismo, o consumismo, o individualismo possessivo e a avareza, a forma "mais evidente de subdesenvolvimento moral" (Paulo VI, 1967:19).

A encíclica criticava a concentração da propriedade e apresentava uma defesa explícita da necessidade de equidade na distribuição da terra.

A terra foi dada a todose não apenas aos ricos. Quer dizer quea propriedade privada não constitui para ninguém um direito incondicional e absoluto. Ninguém tem direito de reservar para seu uso exclusivo aquilo que é supérfluo, quando a outros falta o necessário. Numa palavra, o direito de propriedade nunca deve exercer-se em detrimento do bem comum (Paulo VI, 1967:23).

Os países em via de desenvolvimento não poderiam arcar com altas taxas de juros que multiplicavam suas dívidas, comprometendo as oportunidades de desenvolvimento autônomo, era preciso substituir as relações de dependência e de neocolonialismo (Paulo VI, 1967:52-54).

Enquanto o Vaticano demonstrava seu perfil progressista e desenvolvimentista, no Brasil o período inaugurou a fase mais violenta da ditadura.

A partir de 1968, em paralelo ao aprofundamento da "linha dura", D. Helder passou a estimular as ações pastorais das CEBs, que se disseminaram especialmente pelo Nordeste, a partir do Projeto Esperança, criado pelo arcebispo. 
Na Conferência Geral do Episcopado Latino-Americano, ocorrida em 1968 em Medellín, convocada com o objetivo de levar a cabo os preceitos do Concílio Vaticano II, “a temática da libertação, já presente em alguns meios pastorais, é recebida pelo episcopado (...) com a rejeição, ainda que parcial, dos esquemas desenvolvimentistas" (Andrade, 2008:2). Desde o Concílio, de 1962 a 1965, gestou-se uma teologia amparada nas lutas sociais. Os padres Henrique Vaz e Almery Bezerra passaram a publicar textos defendendo uma ação mais engajada e popular da Igreja, estariam "sendo lançadas as bases da Teologia da Libertação" (Neto, 2012:56). Em 1970, foi convocado o I Congresso da Teologia da Libertação, realizado em Bogotá.

Em 1971, Gustavo Gutierrez publicou A Teologia da Libertação, que procurava apresentar uma teologia com base nas particularidades latino-americanas, incorporando elementos mais radicais do marxismo às análises sociais e políticas da esquerda católica, como a da luta de classes, aproximando-se das teses da teoria da dependência e do socialismo. Embora tributária do humanismo comunitarista de Lebret e Mounier, a Teologia da Libertação rompia com a defesa da aliança de classes própria do desenvolvimentismo.

A Conferência de Medellín denunciou as injustiças sociais e sugeriu um maior engajamento da Igreja na luta por mudanças estruturais, econômicas, sociais e políticas na América Latina. Medellín deu origem ao Documento Justiça e Paz, assinado por D. Helder Câmara, Gustavo Gutiérrez e José Grimillion, um expresso combate às ditaduras latino-americanas e à opressão dos trabalhadores.

Segundo Löwy (1989), primeiro veio a práxis libertadora da Igreja, solidária aos pobres e com uma ação conscientizadora, que não os entendia como vítimas passivas que requeressem caridade e assistência, mas como sujeitos potenciais de sua própria libertação. Só depois se construiu uma teologia partida do olhar da América Latina e de suas contradições sociais.

A teologia da libertação não é a origem do cristianismo radical, mas sim, como insistem os próprios teólogos, o produto, o resultado de toda uma prática, de uma experiência anterior - a começar pela JUC brasileira de 1960-1962 (...) no final dos anos 60, já havia na Igreja da América Latina toda uma práxis libertadora (...) a teologia, portanto, veio num segundo 
momento. E veio como expressão desta prática libertadora da Igreja (Löwy, 1989:14).

D. Helder nunca foi um teólogo, não obstante, sua práxis levou Leonardo Boff a considerá-lo o pai fundador da Teologia da Libertação.

(...) mais do que Gustavo Gutierrez e João Luiz II, o verdadeiro pai da Teologia da Libertação foi Helder Câmara. Ele inaugurou a prática libertadora de trabalhar com os pobres (...) Foi ele que criou a expressão “Libertação integral”, em 1967, na reunião do Celam, em Montevidéu. (...) Ele é o verdadeiro pai, no sentido de que foi o primeiro a inaugurar uma prática da libertação e o primeiro a fazer reflexões profético-pastorais sobre a libertação. Nós teólogos viemos depois (...) Mas o verdadeiro pai, a fonte inspiradora, de prática e de vida, foi Helder Câmara (Boff, 1996: 1).

A posse do Papa Francisco, primeiro pontífice latino-americano, interrompeu mais de três décadas de conservadorismo na Santa Sé. Em meio a um novo aggiornamento na Igreja, o pontífice vem recuperando os princípios do Pacto das Catacumbas, recobrando a agenda voltada para os pobres (Boff, 2013:4), ensejando uma nova primavera progressista (Souza, 2014:105). A pauta política, pastoral, profética e eclesiástica de Francisco, demonstrada por suas ações, discursos e documentos oficiais, vem apresentando claras aproximações com o ideário progressista das décadas de 1960 e 1970, em favor de um "desenvolvimento integral do homem e da humanidade" (Francisco, 2015). Nesse sentido, a abertura de processo de beatificação e canonização de D. Helder Câmara recoloca em destaque o pensamento e as ações do clérigo, representando o reconhecimento da Igreja pelas contribuições pastorais e proféticas do "Bispo da Paz", do "Profeta dos Pobres", em prol de uma Igreja comprometida com a justiça social e a libertação dos oprimidos.

(Recebido para publicação em 24 de setembro de 2017)

(Reapresentado em 11 de março de 2019)

(Aprovado para publicação em 22 de maio de 2019)

\section{NOTAS}

1. O cristianismo profético de Desroche também teve grande recepção no pensamento da esquerda católica no Brasil. D. Helder Câmara teria sido especialmente influenciado pelo livro Sociologia e esperança, do intelectual francês (Rodrigues, 2013). 
2. Entre aqueles que assinaram o manifesto de fundação do movimento encontravam-se os padres Lebret, Marie-Réginald Loew, Alain-Zacharie Serrand, Abbé Pierre Bouche e Marie-Fabien Moos, e os leigos Gustave Thibon, Raymond Delprat, Gaston Bardet, Jean-Marie Gatheron, Alexandre Dubois, Alfred Sauvy, François Perroux, René Moreux e Emmanuel Mounier.

3. As equipes de pesquisa coordenadas por Lebret formularam diagnósticos e planos habitacionais para algumas das mais importantes cidades industriais francesas, como Lyon, Marseille, Grenoble, Saint-Étienne, Nantes e Le Havre.

4. Preocupado com a formação de técnicos especializados na formulação de diagnósticos sociais para o planejamento de ações para o combate à miséria, Lebret publicou vários manuais para a elaboração de levantamentos sociais, como Méthode d'enquête, Guide pratique de l'enquête rurale, Guide de l'enquête urbaine, e Guide pratique de l'enquête sociale (Cestaro, 2010; Valladares, 2012; Angelo, 2010).

5. A expressão "terceiro mundo" foi cunhada por Sauvy em 1952 e generalizou-se após 1955, quando da reunião de Bandung dos 77 países não alinhados à Organização do Atlântico Norte (Otan) e ao Pacto de Varsóvia.

6. Em Drama do século XX, de 1962, e Dinâmica concreta e desenvolvimento, de 1966, Lebret baseava-se nos documentos da Cepal para traçar seus apontamentos sobre o desenvolvimento na América Latina.

7. Logo após a chegada ao Rio de Janeiro, em abril de 1947, Lebret proferiu palestras para sindicalistas, sociólogos, geógrafos e clérigos. Nestes eventos conheceu alguns de seus mais próximos companheiros no Brasil, Josué de Castro, D. Helder Câmara, Alceu Amoroso Lima e José Arthur Rios. No dia 9, chegou em São Paulo, onde foi recebido por Cyro Berlink (Pontual, 2011:5).

8. A École originou-se das articulações entre os membros do grupo Esprit, ligado à Ação Católica e dirigido por Mounier, e do movimento Vie Nouvelle, e reuniu um conjunto de intelectuais que contribuíram com a resistência francesa à invasão nazista, tendo uma rápida existência entre 1940 e 1942 (Angelo, 2010).

9. Em 1947, o padre já havia publicado um estudo comparando a estrutura das habitações de cidades industriais no Brasil e na França, Le logement de la population de São Paulo. Em 1951, publicou Sondagem preliminar a um estudo sobre a habitação em São Paulo, em coautoria com Raymond Delprat. Entre 1953 e 1956, a Sagmacs realizou estudos que redundaram na publicação de Problemas de desenvolvimento: necessidades e possibilidades do Estado de São Paulo e de Estrutura urbana da aglomeração paulistana (Villaça, 1999; Cestaro, 2010; Pontual, 2011; Carneiro, 1988).

10. Seguindo os parâmetros metodológicos utilizados nos estudos sobre São Paulo, a equipe da Sagmacs publicou, em 1961, Estrutura urbana da aglomeração de Belo Horizonte (Pontual, 2011).

11. Em comemoração aos 50 anos de sua publicação, foi editada a coletânea Favelas Cariocas: ontem e hoje (Freire et al., 2012). Orientada por Lebret, a pesquisa teve coordenação de Carlos Alberto de Medina e direção técnica do sociólogo José Arthur Rios, que havia passado por La Tourette, se aproximado do Economia e Humanismo e tornou-se diretor da Sagmacs no Rio (Lima e Maio, 2010). 


\section{REFERÊNCIAS BIBLIOGRÁFICAS}

ANDRADE, Paulo Fernando Carneiro de. (2008), “O desenvolvimento da teologia católica no Brasil". International Network of Societies for Catholic Theology. Disponível em: http://ejesus.com.br/o-desenvolvimento-da-teologia-catolica-no-brasil/. Acessado em $8 / 2 / 2017$.

ANDRADE, Francisco Jatobá de; ARAÚJO, Tarcisio Patricio de (orgs.). (2016), Diálogos com Lebret: 60 anos depois. Recife: Cepe/Ceplan.

ANGELO, Michelly Ramos de. (2010), Les Developpeurs: Louis-Joseph Lebret e a Sagmacs na formação de um grupo de ação para o planejamento urbano no Brasil. Tese (Doutorado em Arquitetura e Urbanismo), Universidade de São Paulo, São Carlos.

BARROS, Marcelo. (2011), Dom Helder Câmara: profeta para os nossos dias. São Paulo: Paulus.

BARROS, Raimundo Caramuru; OLIVEIRA, Lauro de. (2000), Dom Hélder: o artesão da paz. Brasília: Senado Federal.

BEOZZO, José Oscar. (2008), Dom Helder Camara e o Concílio Vaticano II. Rio de Janeiro: Fundação Lauro Campos.

BIELSCHOWSKY, Ricardo. (2000), Pensamento econômico brasileiro: o ciclo ideológico do desenvolvimentismo. Rio de Janeiro: Contraponto.

BOFF, Leonardo. (1996), “Entrevista com Leonardo Boff”. Dhnet. Disponível em: http:/ /www. dhnet.org.br/direitos/militantes/boff/boff_entrevista1.html. Acessado em 22/8/2017.

. (2013), “Primeiro ano do Papa Francisco”. Carta Maior. Disponível em: http:/ /www. cartamaior.com.br/? /Editoria/Internacional/Entrevista-Leonardo-Boff-analisa-primeiro-ano-do-Papa-Francisco/6/29800. Acessado em 8/2/2017.

BOSI, Alfredo. (2012), "Economia e humanismo". Estudos Avançados, v. 26, n. 75, pp. 249-266.

BRANDÃO, Gildo Marçal. (2007), Linhagens do pensamento político brasileiro. São Paulo: Hucitec.

BOTELHO, André. (2008), "Entre afinidades eletivas e escolhas pragmáticas". Estudos Avançados, v. 22, n. 63, pp. 323-326.

. (2012), "Interpretações do Brasil e ciências sociais, um fio de Ariadne". Sinais Sociais, v. 7, n. 20, pp. 10-35.

BUZZAR, Miguel; A.; CORDIDO, Maria Tereza R. Leme; SIMONI, Lucia Noemia. (2012), "Pesquisa e levantamento dos processos relativos aos projetos e obras dos equipamentos públicos implementados pelo plano de ação do governo do estado de São Paulo (Page), gestão Carvalho Pinto (1959-1963)". Arquivo do Instituto de Previdência do Estado de São Paulo - Ipesp. Fórum Patrimônio, n. 1, v. 5, pp. 69-89.

CANDIDO, Antonio. (1999), "Para pensar o problema da fome". Folha de S. Paulo. Disponível em: http://www1.folha.uol.com.br/fsp/ilustrad/fq2911199917.htm. Acessado em $8 / 2 / 2017$.

CARNEIRO, Auner Pereira. (1988), “As reformas paulistanas de 1950 e 1960”. E-GovUFSC. Disponível em: http://www.egov.ufsc.br/portal/conteudo/reformas-paulistanas-de-1950-1960-0. Acessado em 8/2/2017. 
CESTARO, Lucas. (2009), A Sagmacs e o estado da aglomeração paulistana. Dissertação (Mestrado em Arquitetura e Urbanismo), Universidade de São Paulo, São Carlos.

. (2010), “Lebret e o urbanismo da Sagmacs: o Brasil no foco do Mouvement Économie et Humanisme". Seminário da Cidade e do Urbanismo, v. 11, n. 5, pp. 1-11.

CASTRO, Josué de. (1957), Geografia da fome. Rio de Janeiro, O Cruzeiro, $2^{\mathrm{a}}$ ed.

CHIQUITO, E. A. (2010), A Comissão Interestadual da bacia Paraná-Uruguai e o planejamento regional no Brasil (1951-1972). Rio de Janeiro: Encontro Nacional da Anparq, v. 1.

CONDINI, Martinho. (2004), D. Hélder Câmara: modelo de esperança na caminhada para a paz e a justiça social. Dissertação (Mestrado em Ciências da Religião). Pontifícia Universidade Católica, São Paulo.

FAORO, Raymundo. (1987), "Existe um pensamento político brasileiro?" Estudos Avançados, v. 1, n. 1, pp. 9-58.

FERREIRA, Daniela Maria. (2009), "O uso da militância política na constituição de espaços de debates filosóficos no Brasil”. Cadernos CERU, série 2, v. 20, n. 1, pp. 205-222.

FRANCISCO, Papa. (2015), Carta Encíclica Laudato Si. Roma: Vaticano.

FREIRE, Letícia de Luna; et al. (2012), Favelas cariocas: ontem e hoje. Rio de Janeiro, Garamond.

IANNI, Octavio. (2004), Pensamento social no Brasil. Bauru: EDUSC.

JOÃO XXIII, Papa. (1962), Carta Encíclica Matter et Magistra. Roma: Vaticano. . (1963), Carta Encíclica Pacem in Terris. Roma: Vaticano.

LAMPARELLI, Celso Monteiro; LEME, Maria Cristina da Silva. (2001), "A politização do urbanismo no Brasil: a vertente católica". IX Encontro da Anpur, Rio de Janeiro, v. 2, pp. 675-687.

LAMPARELLI, Celso Monteiro. (1994), “Louis-Joseph Lebret e a pesquisa urbano regional no Brasil: crônicas tardias ou história prematura". Espaço e Debates, ano 14, n. 37, pp. 90-99.

LEÃO XIII, Papa. (1891), Carta Encíclica Rerum Novarum. Roma: Vaticano.

LEBRET, Louis-Joseph. (1955), Estudo sobre a implantação de indústrias interessando a Pernambuco e ao Nordeste. Recife: Codepe.

. (1958), "Développement harmonisé et économie humaine". Economia e Humanismo, n.113, pp. 1-6.

. (1960), Investigación sobre lós aspectos humanos del desarrollo. Lyon: Irfed.

LEME, Maria Cristina da Silva. (2012), "Três vertentes do urbanismo em São Paulo". Revista Brasileira de Estudos Urbanos e Regionais/Anpur, v. 6, n. 2, pp. 1-16.

LIMA, Nísia Trindade; MAIO, Marcos Chor. (2010), "Ciências Sociais e educação sanitária: a perspectiva da Seção de Pesquisa Social do Serviço Especial de Saúde Pública da década de 1950". História, Ciências, Saúde - Manguinhos, v. 17, n. 2, pp. 511-526. 
José Henrique Artigas de Godoy

LÖWY, Michel. (1989), "Marxismo e cristianismo na América Latina”. Lua Nova, v. 1, n. 19, pp. 5-21.

LÖWY, Michael. (2011), Sobre o conceito de "afinidade eletiva" em Max Weber. Plural, v. 17, n. 2, pp. 129-142.

LYNCH, Christian Edward Cyril. (2013), "Por que pensamento e não teoria? A imaginação político-social brasileira e o fantasma da condição periférica (1880-1970)". DADOS Revista de Ciências Sociais, v. 56, n. 4, pp. 727-767.

(2016), “Cartografia do pensamento político brasileiro: conceito, história, abordagens". Revista Brasileira de Ciência Política, n. 19, p. 75-119.

MANNHEIM, Karl. (1959), "O pensamento conservador". In: MANNHEIM, Karl, Essays on Sociology and Social Psychology. London: Routledge \& Kegan Paul Ltd., tradução de Sylvia Lyra, pp. 74-119.

MARITAIN, Jacques. (1945), Cristianismo e democracia. Rio de Janeiro: Agir.

MENEZES NETO, Antonio Júlio. (2012), A ética da teologia da libertação e o espírito do socialismo no MST. Belo Horizonte: Ed. UFMG.

PAULO VI, Papa. (1967), Carta Encíclica Populorum Progressio. Roma: Vaticano.

PELLETIER, Denis. (1996), Économie et humanisme: de l'utopie communautaire au combat pour le Tiers Mond, 1941-1966. Paris: Cerf.

PILETTI, Nelson; PRAXEDES, Walter. (1997), Dom Helder Câmara: entre o poder e a profecia. São Paulo: Ática.

PIO XI, Papa. (1931), Carta Encíclica Quadragesimo Anno. Roma: Vaticano.

PONTUAL, Virgínia. (2000), “O urbanismo no Recife: entre ideias e representações”. Revista Brasileira de Estudos Urbanos e Regionais, n. 2, pp. 89-108.

. (2011), “O engenheiro Antônio Bezerra Baltar: prática urbanística, Cepur e Sagmacs”. Revista Brasileira de Estudos Urbanos e Regionais, v. 13, n. 1, pp. 151-169.

QUIROGA, Ana Maria. (2011), "Paulo Freire e a modernização cultural brasileira". Revista da Faculdade de Educação, ano IX, n. 16, pp.153-168.

RAMPON, Ivanir. (2014), "A amizade espiritual entre Paulo VI e Dom Helder Câmara". IHU On-Line, p.1-6. Disponível em: http://www.ihu.unisinos.br/entrevistas/536888-paulo-vi-e-dom-helder-camara-uma-amizade-espiritual-entrevista-especial-com-ivanir-rampon. Acessado em 8/2/2017.

RIDENTI, Marcelo. (1998), O romantismo revolucionário da Ação Popular: do cristianismo ao maoismo. Chicago, Lasa.

RIOS, José Arthur. (2012). “Aspectos humanos das favelas cariocas, 50 anos: uma avaliação. In: L. L. Freire et al. (orgs.), Favelas cariocas: ontem e hoje. Rio de Janeiro: Garamond.

ROCHA, Dom Geraldo Lyrio. (2009), Dom Helder Camara: profeta da justiça e mensageiro da esperança. Mariana: CNBB.

DADOS, Rio de Janeiro, vol.63(1): e20170188, 2020. 
RODRIGUES, Rogério Pamponet. (2013), “Cristianismo profético: esperança e utopia em Helder Camara, Henri Desroche e na JMJ do Papa Francisco no Brasil”. Revista Estudos da Religião, v. 27, n. 2, pp. 249-269.

SCHALLENMUELLER, Christian Jecov. (2010), A Conferência Nacional dos Bispos do Brasil - CNBB (1952-1964): emergência de uma nova elite católica e colaboração com o desenvolvimento. Curitiba, Seminário Nacional de Sociologia e Política.

SILVA, Wellington Teodoro da. (2011), Revolução, tradição e religião: o catolicismo nas veredas da politica: o jornal Brasil, Urgente (1963-1964). Curitiba: CRV.

SOARES, Edvaldo. (2014), Pensamento católico brasileiro: influências e tendências. Marília, Oficina Universitária/Cultura Acadêmica.

SOUZA, Adenilson Ferreira de. (2015), Desenvolvimento, democracia e justiça social no pensamento de Dom Helder Camara (1931-1985). Tese (Doutorado em Ciência Política), Universidade Federal de Minas Gerais, Belo Horizonte.

SOUZA, Luiz Alberto Gomez de. (2009), D. Helder, irmão dos pobres: um testemunho no ano de seu centenário. Rio de Janeiro, PUC/RJ.

SOUZA, Luiz Alberto Gomez de. (2014), "A guinada da Igreja Católica à direita". Insight Inteligência, ed. 66, n. XVIII, pp. 94-105.

VALLADARES, Licia do Prado. (2005), A invenção da favela: do mito de origem a favela.com. Rio de Janeiro: FGV.

. (2012), "A descoberta do trabalho de campo em 'Aspectos Humanos da Favela Carioca'”. In: L. L. Freire et al. (orgs.), Favelas cariocas: ontem e hoje. Rio de Janeiro: Garamond, pp. 65-100.

VATICANO II, Concílio. (1965), Constituição Pastoral Gaudium et Spes. Roma: Vaticano.

VIANNA, Luiz Werneck. (2001), “O pensar e o agir”. Lua Nova, n. 54, pp. 35-42.

VILLAÇA, Flávio. (1999), “Uma contribuição para a história do urbanismo". In: C. Deák; S. Schiffer (orgs.), O processo de urbanização no Brasil. [S.l: s.n.], 2010. 
José Henrique Artigas de Godoy

RESUMO

Dom Helder Câmara e Louis-Joseph Lebret: Desenvolvimentismo e Práxis Progressista Católica nas Décadas de 1950 e 1960

O artigo versa sobre o pensamento e a ação política do arcebispo Dom Helder Câmara e do padre Louis-Joseph Lebret nas décadas de 1950 e 1960. Objetiva-se refletir sobre a formação de uma linhagem progressista do pensamento católico no Brasil, destacando particularmente sua vertente desenvolvimentista. Nesse sentido, acompanham-se as trajetórias dos clérigos, concernindo aspectos biográficos, da formação intelectual, técnica, filosófica e eclesiástica, assim como suas redes de relacionamento, as formas de recepção de suas ideias, suas participações nos debates internos à Igreja e ainda as relações de colaboração com os governos nacional-desenvolvimentistas, revelando suas contribuições para a práxis transformadora que precedeu a gestação de um viés revolucionário da esquerda católica na América Latina, marcante na formação da Teologia da Libertação. $\mathrm{O}$ estudo do pensamento dos clérigos ganha relevo contemporâneo em face da recente reabilitação e revalorização de ícones da esquerda católica latino-americana e da retomada da Doutrina Social da Igreja, ensejada na plataforma progressista da gestão do Papa Francisco, que mantém vínculos estreitos com a matriz desenvolvimentista do pensamento católico e com princípios da Teologia da Libertação.

Palavras-chave: Louis-Joseph Lebret; Dom Helder Câmara; desenvolvimentismo; economia e humanismo; esquerda católica

\section{ABSTRACT \\ Dom Helder Camara and Louis-Joseph Lebret: Developmentalism and Progressive Catholic Praxis in the 1950s and 1960s}

The article deals with the thought and political action of Archbishop Helder Camara and Priest Louis-Joseph Lebret in the 1950s and 1960s. The goal is to reflect on the formation of a progressive lineage of Catholic thought in Brazil, particularly highlighting its developmental aspect. Thus, the trajectories of these clerics are followed, concerning the following aspects: biographical issues, intellectual, technical, philosophical and ecclesiastical formation, as well as their relationship networks, how their ideas were received, their participation in internal debates in the Church and also their collaborative relations with national-developmental governments, revealing their contributions to the transformative praxis that preceded the gestation of a revolutionary bias of the Catholic left in Latin America, which marked the formation of Liberation Theology. The study of these clerics' thinking gains contemporary prominence if we take into account the recent rehabilitation and revaluation of icons of the Latin American Catholic left and the 
resumption of the Church's Social Doctrine, based on Pope Francis' progressive platform, which maintains close ties with the developmental matrix of Catholic thought and certain principles of Liberation Theology.

Keywords: Louis-Joseph Lebret; Dom Helder Câmara; developmentalism; economics and humanism; catholic left

\section{RÉSUMÉ}

Dom Helder Camara et Louis-Joseph Lebret: développementalisme et praxis catholique progressiste dans les années 1950 et 1960

L'article traite de la pensée et de l'action politique de l'archevêque Helder Camara et du père Louis-Joseph Lebret dans les années 1950 et 1960. L'objectif est de réfléchir à la formation d'une lignée progressive de la pensée catholique au Brésil, en mettant particulièrement en évidence son aspect développementaliste. En ce sens, il suit les trajectoires des religieux, en ce qui concerne les aspects biographiques, la formation intellectuelle, technique, philosophique et ecclésiastique, ainsi que leurs réseaux relationnels, les manières de recevoir leurs idées, leur participation aux débats internes à des relations de collaboration avec des gouvernements développementalistes nationaux, révélant leurs contributions à la praxis transformatrice qui a précédé la gestation d'un parti pris révolutionnaire de la gauche catholique en Amérique latine, qui a marqué la formation de la théologie de la libération. L'étude de la pensée cléricale prend de l'importance aujourd'hui face à la récente réhabilitation et à la revalorisation des icônes de la gauche catholique latino-américaine et à la reprise de la doctrine sociale de l'Église, fondée sur la plate-forme progressive du management du pape François, qui entretient des liens étroits avec la matrice développementiste de la pensée catholique et des principes de la théologie de la libération.

MOTS-CLÉS: Louis-Joseph Lebret; Dom Helder Câmara; développementalisme; économie et humanisme; la gauche catholique 


\section{RESUMEN}

Don Helder Câmara y Louis-Joseph Lebret: desarrollismo y práxis progresista católica en las décadas de 1950 y 1960

El artículo versa sobre el pensamiento y la acción política del arzobispo Don Helder Câmara y del padre Louis-Joseph Lebret en las décadas de 1950 e 1960. Se pretende reflexionar sobre la formación de un linaje progresista del pensamiento católico en Brasil, destacando particularmente su vertiente desarrollista. En ese sentido, se acompañan las trayectorias de los clérigos, concerniendo aspectos biográficos, de la formación intelectual, técnica, filosófica y eclesiástica, así como sus redes de relaciones, las formas de recepción de sus ideas, sus participaciones en los debates internos de la Iglesia y, además, las relaciones de colaboración con los gobiernos nacional-desarrollistas, revelando sus contribuciones para la praxis transformadora que precedió la gestación de una tendencia revolucionaria de la izquierda católica en América Latina, central en la formación de la Teología de la Liberación. El estudio del pensamiento de los clérigos adquiere importancia contemporánea dada la reciente rehabilitación y revalorización de íconos de la izquierda católica latinoamericana y de la recuperación de la Doctrina Social de la Iglesia, que se enmarca en la plataforma progresista de la gestión del Papa Francisco, que mantiene vínculos estrechos con la matriz desarrollista del pensamiento católico y con principios de la Teología de la Liberación.

Palabras clave: Louis-Joseph Lebret; Don Helder Câmara; desarrollismo; economía y humanismo; izquierda católica 